\title{
Pengaruh Profitabilitas terhadap Nilai Perusahaan dengan Moderasi Pengungkapan Elemen-Elemen Integrated Reporting
}

\author{
Gilang Ryanda Bhimantara ${ }^{1}$ \\ Jurusan Akuntansi \\ Politeknik Keuangan Negara STAN, \\ Indonesia
}

\author{
Agung Dinarjito ${ }^{2}$ \\ Jurusan Akuntansi \\ Politeknik Keuangan Negara STAN, \\ Indonesia
}

Surel : agung.dinarjito@pknstan.ac.id

ABSTRAK

Penelitian ini bertujuan untuk mengetahui pengaruh profitabilitas terhadap nilai perusahaan serta moderasi pengungkapan elemen-elemen integrated reporting dalam mempengaruhi hubungan profitabilitas dengan nilai perusahaan. Sampel merupakan perwakilan dari masing-masing sektor dengan menggunakan metode purposive stratified sampling. Penelitian ini merupakan penelitian kuantitatif yang menggunakan sampel 86 perusahaan terdaftar di Bursa Efek Indonesia (BEI). Data dianalisis menggunakan regresi linear berganda dan diolah menggunakan aplikasi Stata 13. Hasil penelitian menunjukkan bahwa profitabilitas tidak berpengaruh terhadap nilai perusahaan. Investor masih perlu menimbang informasi yang dihasilkan dari profitabilitas karena adanya opsi laba ditahan dan pembagian dividen yang ditindaklanjuti oleh perusahaan. Hasil selanjutnya menyatakan bahwa elemen integrated reporting tidak mempengaruhi hubungan profitabilitas dengan nilai perusahaan karena nilai informasi dalam pengungkapan elemen tidak berkaitan langsung dengan informasi finansial (angka) suatu perusahaan.

Kata Kunci: Profitabilitas; Integrated Reporting; Nilai Perusahaan.

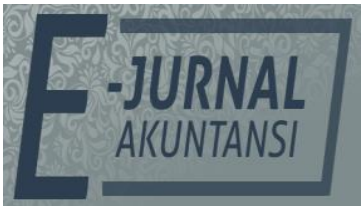

e-ISSN 2302-8556

Vol. 31 No. 4

Denpasar, April 2021

Hal. 996-1009

DOI:

10.24843/EJA.2021.v31.i04.p16

PENGUTIPAN :

Bhimantara, G.R., \& Dinarjito,

A. (2021). Pengaruh

Profitabilitas terhadap Nilai

Perusahaan dengan Moderasi

Pengungkapan Elemen-

Elemen Integrated Reporting.

E-Jurnal Akuntansi, 31(4), 996-

1009

RIWAYAT ARTIKEL:

Artikel Masuk:

15 Februari 2021

Artikel Diterima:

24 April 2021

This paper aims to determine the effect of profitability on firm value and the moderation of disclosure of integrated reporting elements in influencing the relationship of profitability with firm value. The sample is representative of each sector using the purposive stratified sampling method. This research is a quantitative study using a sample of 86 companies listed on the Indonesia Stock Exchange (BEI). Data were analyzed using multiple linear regression and processed using the Stata 13 application. The results show that profitability has no effect on the value of the company. Investors still need to consider the information generated from profitability because of the option to put into retained earnings and dividend distribution that will be taken by the company. The other result state that the integrated reporting elements do not affect the relationship of profitability with firm value because the value of information in the disclosure element is not directly related to the financial information (numbers) of a company.

Keywords: $\quad$ Profitability; Firm Value; Integrated Reporting.

Artikel dapat diakses : https://ojs.unud.ac.id/index.php/Akuntansi/index 


\section{PENDAHULUAN}

Setiap perusahan akan berusaha melakukan kinerja untuk memperoleh profit atau keuntungan yang optimal dengan tujuan diantaranya meningkatkan kekayaan pemilik (Titman, Keown, \& Martin, 2018) dan memaksimalkan nilai perusahaan yang tercermin pada harga sahamnya. Dengan adanya profit, perusahaan memiliki kelebihan untuk melakukan kegiatan ekonomi seperti melakukan ekspansi atau memberikan dividen kepada pemegang saham. Ekspansi dilakukan perusahaan agar lebih dikenal oleh publik dan semakin berkembang. Pembagian dividen dilakukan jika kegiatan investasi atau ekspansi perusahaan sedang tidak perlu untuk dilakukan.

Gibson (2001) menyatakan dalam penelitian Mufidah \& Purnamasari, (2018) bahwa kemampuan perusahaan untuk menghasilkan profit disebut profitabilitas. Kemampuan ini menjadi penting karena investor akan mengetahui keberlangsungan hidup suatu perusahaan dan menilai kinerja manajemen dalam mengelola perusahaan. Berdasarkan teori dividen, perusahaan dapat mendistribusikan profit kepada pemegang saham atau menjadi laba ditahan perusahaan. Selain itu, profitabilitas menjadi informasi yang diperhatikan karena berkaitan dengan pertumbuhan perusahaan dan potensi dividen yang akan diterima oleh investor. Investor memiliki pandangan yang berbeda terhadap tindak lanjut dari profitabilitas perusahaan. Dalam teori Gordon (1959), beberapa investor menyukai pembagian dividen karena memperoleh tambahan kekayaan secara langsung dan lebih pasti daripada keuntungan capital gains. Dalam teori Lang \& Litzenberger (1989), beberapa investor lebih menyukai capital gains karena dapat menunda pembayaran pajak. Dengan tidak membagi dividen kepada investor, perusahaan memiliki profit yang dapat dikelola dengan baik sehingga growth perusahaan menjadi tinggi. Dengan begitu, capital gains akan naik dan diikuti kenaikan nilai perusahaan.

Perubahan nilai perusahaan yang diukur menggunakan kenaikan atau penurunan harga pasar saham menjadi daya tarik bagi investor dan calon investor dalam menetukan keputusan investasinya. Menurut Jusriani \& Rahardjo (2013) nilai perusahaan merupakan nilai atau harga yang bersedia dibayarkan oleh investor yang tercermin dalam harga saham. Investor dan calon investor mengalihkan sebagian kekayaannya dalam bentuk saham suatu perusahaan untuk melakukan invetasi yang memberikan imbal hasil sesuai yang diharapkannya.

Dewasa ini, perkembangan teknologi membuat perubahan dunia bisnis semakin pesat. Salah satu contoh perkembangan teknologi terkait perusahaan adalah memberikan kemudahan akan keterbukaan informasi sehingga memudahkan stakeholder dalam mengambil keputusan. Namun, perkembangan ini juga memberi efek negatif seperti biasnya informasi ekonomi yang disajikan perusahaan. PT Jaya Agra Wattie Tbk (JAWA), perusahaan yang listed di BEI yang bergerak di sektor perkebunan, mengalami kenaikan nilai saham di awal tahun 2017 sedangkan kinerja perusahaan mengalami kerugian pada periode tahun 2016. Hal ini terjadi karena investor mendapat sentimen positif dari kenaikan harga karet secara global.

Dalam prinsip keuangan, Titman et al. (2018) menyatakan bahwa harga saham akan direfleksikan oleh informasi yang dihasilkan oleh perusahaan. Pada 
saat perusahaan mendapatkan kinerja yang baik (good news), maka harga saham cenderung akan naik, dan begitupun sebailknya saat kinerja perusahan buruk (bad news), maka harga saham akan cenderung turun. Namun, ternyata peningkatan saham tidak seiring dengan kinerja emiten yang mencatatkan rugi bersih (Rahmayanti, 2017).

Selain PT Jaya Agra Wattie Tbk (JAWA), Perusahaan lainnya yaitu PT Smartfren Telecom Tbk (FREN) yang bergerak di bidang telekomunikasi mengalami kenaikan saham sebesar 132\% sejak awal Januari hingga Juli 2019 meskipun perusahaan mengalami rugi bersih selama 12 tahun terakhir (Saleh, 2019). Hal ini disebabkan karena Investor domestik menaruh harapan besar atas pertumbuhan perusahaan kendati investor asing melepas saham FREN hingga Rp 13,07 miliar di pasar.

Fenomena terkait perusahaan JAWA dan FREN memantik pertanyaan kenapa kondisi tersebut dapat terjadi. Fenomena ini bertentangan dengan beberapa hasil penelitian terdahulu. Wijaya \& Sedana (2015) menyatakan perusahaan yang mengalami peningkatan laba mencerminkan bahwa perusahaan mempunyai kinerja yang baik sehingga menimbulkan sentimen positif dari investor. Mufidah \& Purnamasari (2018) menyatakan profitabilitas menggambarkan perusahaan dalam kondisi menguntungkan sehingga nilai perusahaan akan menjadi tinggi. Santoso \& Ariefiantoro (2019) menyatakan profitabilitas memberikan sinyal positif kepada investor tentang prospek pertumbuhan entitas di masa depan. Sucuahi \& Cambarihan (2016) menyatakan kenaikan kinerja perusahaan mempengaruhi competitive advantage sehingga meningkatkan value perusahaan. Penelitian yang dilakukan oleh Wijaya \& Sedana (2015), Sucuahi \& Cambarihan (2016), Mufidah \& Purnamasari (2018), dan Santoso \& Ariefiantoro (2019) secara umum menyimpulkan hasil bahwa profitabilitas memiliki pengaruh terhadap nilai perusahaan. Hasil ini juga menggambarkan bahwa terdapat perbedaan antara bukti empiris dari hasil penelitian dengan fenomena yang terjadi. Hal ini menunjukkan bahwa saat ini, perekonomian menghadapi paradigma akan value informasi yang dihasilkan perusahaan. Adanya perbedaan fenomena dan hasil penelitian terdahulu, penulis menyusun hipotesis yang pertama yaitu sebagai berikut.

$\mathrm{H}_{1}$ : Profitabilitas berpengaruh positif terhadap nilai perusahaan.

Sumber informasi yang dihasilkan perusahaan berupa laporan perusahaan terus mengalami perkembangan yang oleh (Lisa, 2013) disebut sebagai evolusi pelaporan perusahaan. Laporan perusahaan dimulai dari bentuk financial reporting yang beberapa kali mengalami perubahan sampai sustainability reporting dan yang terakhir berbentuk integrated reporting sebagai upaya untuk memenuhi tuntutan stakeholder. Tahun 1999, Global Reportive Initiative (GRI) menggagas sustainability reporting sebagai laporan perusahaan mengenai informasi dampak sosial, lingkungan dan ekonomi dari aktivitas perusahaan. Pada tahun 2011, International Integrated reporting Committee (IIRC) didukung oleh GRI mengembangkan kerangka pelaporan model baru yang disebut Integrated reporting (IR) sebagai sebuah solusi dalam rangka menjawab kebutuhan pemangku kepentingan. IIRC (2011) menyatakan bahwa integrated reporting menyajikan berbagai informasi material perusahaan seperti prospek, strategi, tata kelola dan informasi lain yang dapat memberikan informasi secara terintegrasi kepada semua pihak yang 
berkaitan. Konsep IR adalah menggambarkan hubungan antar bagian-bagian informasi yang disajikan perusahaan.

Penyusunan laporan berbentuk IR terdiri dari 8 elemen (IIRC, 2011). Elemen ini merupakan unsur- unsur atau bagian-bagian utama yang disajikan dalam laporan perusahaan berbentuk IR. Unsur-unsur tersebut yang harus dipenuhi agar dapat menjadi laporan yang terintegrasi. Salah satu elemen pengungkapan integrated reporting adalah outlook atau prospek. Elemen ini mengaitkan peluang perusahaan terhadap kondisi industri atau ekonomi secara umum. Menurut Muamar (2019) adanya prospek cerah perusahaan seperti pembangunan beberapa bandara dan proyek rumah sakit membuat investor memborong saham PT Wijaya Karya Bangunan Gedung Tbk (WEGE). Laba bersih WEGE meningkat hanya 3,25\% sedangkan kinerja saham membukukan kenaikan sebesar 32,5\%. Prasetio (2019) menyatakan bahwa saham Waskita Karya Persero di tahun 2018 sempat mengalami penurunan harga hingga 55\%. Padahal, emiten ini mencatatkan pertumbuhan laba yang sangat besar dalam periode 5 tahun. Penurunan terjadi karena nilai tukar rupiah melemah terhadap dolar AS serta rasio utang yang tinggi karena Bank Indonesia menaikkan suku bunga. Akibatnya, investor merasa panik dan kemudian menjual emiten tersebut di harga bawah. Fenomena ini menunjukkan bahwa jika prospek usaha bagus, saham perusahaan akan naik. Begitu pula sebaliknya, jika prospek usaha buruk, saham perusahaan akan menurun. Hal ini senada dengan penelitian Lee \& Yeo (2016) yang menyatakan bahwa IR memiliki asosiasi positif terhadap nilai perusahaan. IR dianggap memberikan benefit yang lebih tinggi dibandingkan cost perusahaan. Barth et al., (2017) menyatakan bahwa IR menambah value informasi perusahaan. Hal ini terjadi karena IR dapat menghilangkan informasi asimetri dan membuat patisipan capital market mengambil keputusan yang tepat. Martina (2019) menyatakan pengungkapan IR memberikan sinyal kepada stakeholder mengenai kondisi perusahaan. Sinyal ini diterjemahkan stakeholder sebagai berita baik dari perusahaan sehingga dapat meningkatkan nilai perusahaan.

Penelitian Lee \& Yeo (2016) dan Barth et al., (2017) melakukan studi terhadap perusahaan yang terdaftar di Afrika Selatan sedangkan penelitian Martina (2019) melakukan studi terhadap perusahaan manufaktur yang terdaftar di BEI pada tahun 2017. Lee \& Yeo (2016), Barth et al., (2017), dan Martina (2019) secara umum menyatakan bahwa IR memiliki pengaruh terhadap nilai perusahaan. Namun, ketiga penelitian tersebut memiliki hasil yang berbeda dengan penelitian oleh Sebti (2019) yang melakukan studi terhadap perusahaanperusahaan di Asia bahwa IR tidak berpengaruh terhadap nilai perusahaan. Stakeholders dianggap belum bisa memanfaatkan keluasan informasi integrated reporting sebagai nilai tambah evaluasi pengambilan investasi mereka dan IR dianggap belum mampu memberikan nilai sesuai dengan kualitas perusahaan. Adanya perbedaan hasil penelitian mengenai pengaruh IR terhadap nilai perusahaan, penulis membangun hipotesis yang kedua yaitu sebagai berikut.

$\mathrm{H}_{2}$ : Elemen-elemen integrated reporting memiliki pengaruh positif terhadap hubungan profitabilitas dengan nilai perusahaan.

Adanya fenomena unik terkait pengaruh profitabilitas, perkembangan bentuk laporan perusahaan dan tidak sinkronnya hasil penelitian terdahulu terkait IR membuat peneliti tertarik untuk melakukan penelitian yang berjudul 
"Pengaruh Profitabilitas terhadap Nilai Perusahaan dengan Moderasi Pengungkapan Elemen-Elemen Integrated reporting."

\section{METODE PENELITIAN}

Pendekatan penelitian yang digunakan dalam penelitian ini adalah penelitian kuantitatif. Data diambil dari laporan keuangan perusahaan dan laporan tahunan (annual report) yang diperoleh dari laman Bursa Efek Indonesia (idx.co.id)

Objek penelitian yang digunakan dalam penelitian merupakan perusahaan nonkeuangan yang terdaftar di Bursa Efek Indonesia pada tahun 2016-2018. Kurun waktu tiga tahun diambil dengan mempertimbangkan ketersediaan data dan mewakili tahun-tahun terakhir data yang tersedia untuk umum sehingga dapat mewakili fenomena yang terjadi. Pembatasan terhadap sektor keuangan dilakukan karena karakteristik industri yang berbeda.

Jumlah populasi perusahaan yang terdaftar di BEI menurut website idx.co.id sampai dengan bulan Mei 2020 untuk seluruh sektor kecuali nonkeuangan adalah 596 perusahaan. Namun tidak semua perusahaan tersebut akan dipilih menjadi objek penelitian. Pemilihan sampel dalam penelitian ini menggunakan minimum sampel yang diukur dengan formula slovin (Setiawan, 2007) dalam Kustiani (2017) sebagai berikut.

$$
N=\frac{N}{N d^{2}+1}
$$

Dimana:

n $\quad=$ jumlah sampel

$\mathrm{N} \quad=$ jumlah populasi

$\mathrm{d} \quad=$ galat pendugaan (error tolerance)

Teknik pengambilan sampel adalah dengan menggunakan teknik proportional stratified sampling yaitu sampel yang dipilih secara proporsional berdasarkan kriteria yang ditentukan. Kemudian, diambil beberapa perusahaan dengan proporsi jumlah perusahaan dalam suatu sektor terhadap jumlah sampel keseluruhan. Pemilihan sampel juga mengeliminasi perusahaan-perusahaan dengan kriteria yang ditentukan.

Dalam penelitian ini, variabel dependen adalah nilai perusahaan. Nilai perusahaan merupakan persepsi investor terhadap tingkat keberhasilan perusahaan yang dikaitkan dengan harga saham. Harga saham mengalamai kenaikan menunjukkan nilai perusahaan juga naik. Kenaikan nilai perusahaan menggambarkan perilaku pasar yang percaya akan kinerja perusahaan saat ini dan prospek perusahaan kedepannya. Nilai perusahaan akan diukur menggunakan PBV dengan skala rasio karena proksi ini lebih mencerminkan kenaikan dan penurunan nilai pasar perusahaan terhadap nilai buku perusahaan.

Variabel independen dalam penelitian ini adalah profitabilitas. Dalam Titman et al. (2018) profitabilitas adalah kemampuan perusahaan memperoleh return yang cukup dari hasil investasinya. Perusahaan mengelola dengan baik sumber daya yang dimiliki dan dikuasai untuk memperoleh return (imbal hasil) yang diharapkan. Variabel profitabilitas akan diukur menggunakan ROA dari BEI dengan skala rasio karena proksi pengukuran ini menggambarkan bagaimana manajemen mengelola biaya (cost control) yang dikeluarkan dan mengelola aset (asset efficiency) untuk menghasilkan pendapatan. Dalam penelitian Mufidah \& 
Purnamasari (2018) dan Santoso \& Ariefiantoro (2019) rasio profitabilitas menggambarkan tingkat keuntungan perusahaan yang diantaranya diukur menggunakan rasio Retun on Asset (ROA). Setiap return akan muncul dari cara manajemen mengelola sumber daya (asset) yang dikuasai.

Penelitian ini menggunakan variabel pengungkapan elemen-elemen IR sebagai variabel moderasi. Variabel pengungkapan elemen-elemen IR berdasarkan IR framework terdapat 8 elemen pengungkapan, yaitu Organizational overview and external environment, Governance, Opportunities dan risk, Strategy and resource allocation, Bussiness model, Performance, Outlook, dan Basis of presentation. Variabel ini akan diukur menggunakan skala nominal dengan cara memberikan penilaian angka 1 pada setiap masing-masing elemen yang telah diterapkan dan angka 0 untuk elemen yang tidak diterapkan perusahaan kemudian dilakukan penjumlahan. Perolehan elemen-elemen ini dilakukan dengan metode analisis isi laporan perusahaan. Kustiani (2016) menyatakan skor masing-masing perusahaan digunakan untuk menilai tingkat penerapan IR pada laporan perusahaan.

Variabel kontrol yang digunakan dalam penelitian ini adalah ukuran perusahaan dan leverage. Semakin besar ukuran perusahaan membuat kualitas perusahaan lebih dikenal masyarakat (Sari \& Priyadi, 2016). Ukuran perusahan dijadikan variabel kontrol oleh Lee \& Yeo (2016) dan Barth et al., (2017). Ukuran perusahaan diukur menggunakan logaritma dari total asset. Tingginya hutang perusahaan akan berdampak terhadap kepercayaan publik kepada perusahaan (Sari \& Priyadi, 2016). Pembayaran bunga hutang akan mengurangi laba perusahaan sehingga mengecilkan potensi dividen yang diterima oleh investor. Pengukuran leverage menggunakan jumlah total hutang dibagi dengan ekuitas. Leverage dijadikan sebagai variabel kontrol oleh Bart et al. (2017).

Model persamaan regresi dalam penelitian adalah sebagai berikut.

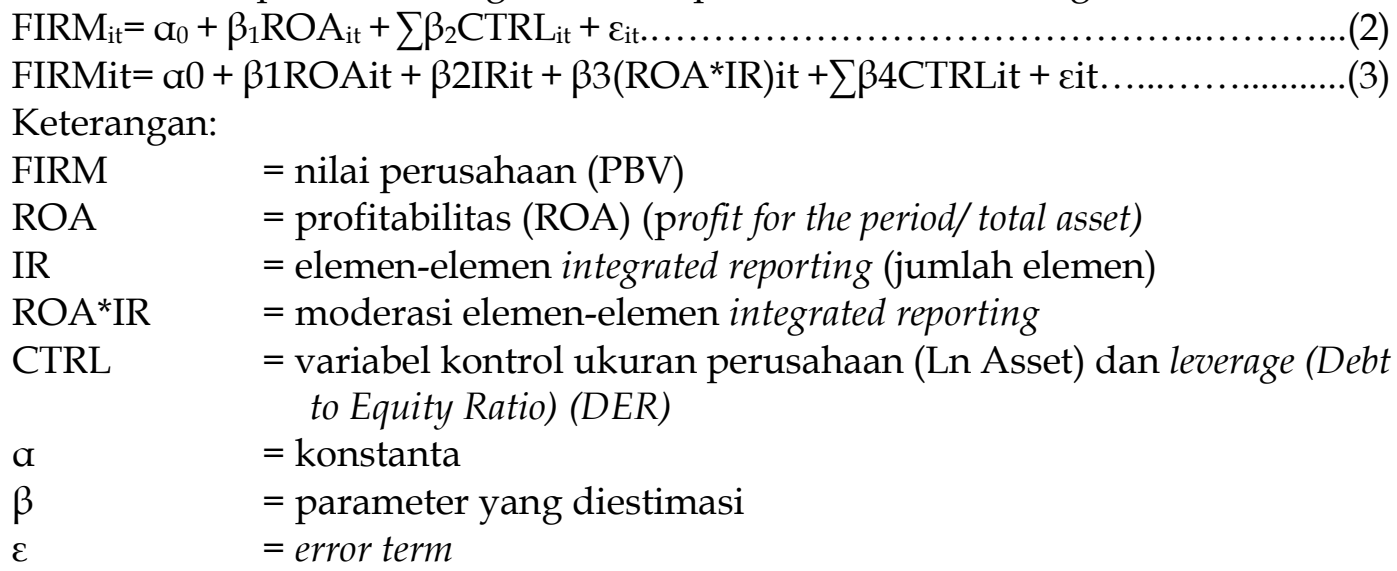

\section{HASIL DAN PEMBAHASAN}

Berdasarkan hasil perhitungan slovin dengan toleransi kesalahan yang ditentukan sebesar $10 \%$, diperoleh ukuran sampel minimum sebesar 85,63 perusahaan seperti perhitungan sebagai berikut.

$\mathrm{n}=\frac{596}{596(10 \%)^{2}+1}=85,63$

Berdasarkan hasil perhitungan slovin, kemudian dilakukan penyesuaian jumlah menjadi 86 perusahaan. Pengelompokan perusahaan tersebar secara proporsional 
terhadap seluruh kelompok industri yang dapat dilihat dalam Tabel 1, dengan kurun waktu 3 tahun, jumlah objek observasi menjadi 258 objek.

Tabel 1. Pengelompokan Sampel Perusahaan

\begin{tabular}{llccc}
\hline No & Sektor & Total & Sampel & Persentase \\
\hline 1 & Agriculture & 22 & 4 & $4 \%$ \\
2 & Basic Industry and Chemicals & 78 & 11 & $13 \%$ \\
3 & Consumer Goods Industry & 58 & 8 & $10 \%$ \\
4 & Infrastructure, Utilities and Tranportation & 78 & 11 & $13 \%$ \\
5 & Mining & 49 & 7 & $8 \%$ \\
6 & Miscellaneous Industry & 51 & 7 & $9 \%$ \\
7 & Property, Real Estate and Building Constr & 89 & 13 & $15 \%$ \\
8 & Trade, Service and Investment & 171 & 25 & $29 \%$ \\
& Total & 596 & 86 & $100 \%$ \\
\hline
\end{tabular}

Sumber: Data Penelitian, 2020

Hasil statistik deskriptif dapat dilihat pada Tabel 2. Berdasarkan Tabel 2, sebaran data nilai perusahaan yang diukur dengan PBV berada di antara nilai 0,14 dan 15,21 dengan rata-rata di angka 1,778915. Hal ini menunjukan bahwa perusahaan-perusahaan yang dijadikan sebagai sampel memiliki nilai pasar yang tidak terlalu jauh dari nilai bukunya karena mendekati nilai 1 (satu) yang artinya apabila perusahaan tersebut dijual, maka memiliki harga pasar yang tidak terlalu jauh dari nilai bukunya. Untuk profitabilitas, sebagian besar perusahaan memperoleh kerugian yang ditandai dari nilai profitabilitas yang negatif. Hal ini terlihat pada nilai rata-rata yang berada pada nilai tengah antara nilai rata-rata dan nilai minimum ROA yang bernilai negatif. Beberapa perusahaan juga memiliki keuntungan pada periode tertentu yang terlihat dari nilai ROA yang positif.

Selanjutnya, berdasarkan Tabel 2, nilai rata-rata perusahaan yang menyampaikan annual report dengan pengungkapan elemen-elemen IR mencapai 5,930233 dari total pengungkapan adalah 8 (delapan) elemen. Nilai ini berada di atas nilai nilai tengah yaitu 4 (empat) elemen sehingga dapat dikatakan bahwa sebagian besar perusahaan telah membuat laporan yang mendekati lengkap dalam pengungkapan elemen-elemen IR pada laporan perusahaannya. Sebaran data perusahaan yang diteliti memiliki nilai aset yang merata. Hal ini terlihat dari nilai rata-rata yang berada pada nilai tengah antara nilai minimal dan nilai maksimal dari nilai logaritma natural total aset. Nilai rata-rata leverage yang mendekati nilai minimal menunjukkan bahwa sebagian besar perusahaan memiliki rasio hutang terhadap ekuitas atau DER dibawah nilai 1.084667 karena nilai LEV kebanyakan berada di rentang antara nilai rata-rata dengan nilai minimal secara keseluruhan. Perusahaan tidak terlalu terbebani akan beban bunga yang harus dibayarkan dan masih memiliki potensi untuk memperoleh pendanaan lebih banyak lagi.

Setelah melakukan uji statistik deskriptif, dilakukan uji spesifikasi model dengan melakukan Uji Chow, Uji BP-LM, dan Uji Haussman. Hasil uji spesifikasi model didapatkan model terbaik adalah fixed effect model (FEM). Kemudian, setelah melakukan uji spesifikasi model, dilakukan uji asumsi klasik. Uji asumsi klasik yang dilakukan adalah uji normalitas, uji multikolinearitas, uji heterokedastisitas dan uji autokorelasi. Dari semua uji asumsi klasik tersebut 
didapatkan bahwa data yang akan diuji telah memenuhi persyaratan uji (data normal, bebas autokorelasi, bebas dari heterokedastisitas, dan bebas dari multikolinearitas).

Tabel 2. Statistik Deskriptif Data Penelitian

\begin{tabular}{llllll}
\hline Variable & Obs & Mean & Std. Dev. & Min. & Max. \\
\hline PBV & 258 & 1.778915 & 1.587237 & .14 & 15.21 \\
ROA & 258 & 3.874764 & 6.336654 & -36.15364 & 22.73068 \\
IR & 258 & 5.930233 & 1.007258 & 4 & 8 \\
SIZE & 258 & 8.800914 & 1.628414 & 5.061636 & 12.75046 \\
LEV & 258 & 1.084667 & 1.165101 & .0128428 & 13.54323 \\
\hline
\end{tabular}

Sumber: Data Penelitian, 2020

Setelah melakukan uji spesifikasi model dan uji asumsi klasik dilakukan uji hipotesis yang terdiri dari dua tahap, yaitu uji signifikansi dan dilanjutkan dengan uji arah. Hasil regresi fixed effect model dapat dilihat pada Tabel 3.

Tabel 3. Ringkasan Regresi Variabel Dependen terhadap Variabel Independen

\begin{tabular}{lllllllll}
\hline & \multicolumn{1}{l}{ Model 1 (Persamaan 1) } & \multicolumn{5}{c}{ Model 1 (Persamaan 2) } \\
\cline { 2 - 9 } Variabel & Coef & t-stat & $\begin{array}{l}\text { Two } \\
\text { Tailed } \\
\text { Prob }\end{array}$ & $\begin{array}{l}\text { One } \\
\text { Tailed } \\
\text { Prob }\end{array}$ & Coef & t-stat & $\begin{array}{l}\text { Two } \\
\text { Tailed } \\
\text { Prob }\end{array}$ & $\begin{array}{l}\text { One } \\
\text { Tailed } \\
\text { Prob }\end{array}$ \\
\hline ROA & .0058282 & 00.43 & 0,671 & 0,3355 & -.0752277 & -1.28 & 0,202 & 0,101 \\
IR & NA & NA & NA & NA & -.2847864 & -2.34 & 0,022 & 0,011 \\
ROAIR & NA & NA & NA & NA & .0146851 & 01.35 & 0,18 & 0,09 \\
SIZE & -.4708119 & -1.23 & 0,222 & 0,111 & -.3752419 & -0.98 & 0,332 & 0,166 \\
LEV & .8015234 & 09.03 & 0.000 & 0.000 & .8020596 & 09.30 & 0.000 & 0.000 \\
Const & 5.030 .521 & 01.50 & 0,137 & 0,0685 & .9089469 & 0,425 & 0.000 & 0.000 \\
$R^{2}$ & 2,839583333 & & & & 2,952083333 & &
\end{tabular}

Catatan: NA = tidak menggunakan variabel tersebut dalam pemodelan

Sumber: Data Penelitian, 2020

Berdasarkan hasil regresi Tabel 3, koefisien determinasi atau $R$-square dari model penelitian ini adalah sebesar 0,4089 untuk model 1 (Persamaan 1) dan 0,4251 untuk model 1 (Persamaan 2). Hal ini menunjukkan bahwa variabel independent pada model regresi yang digunakan dalam penelitian ini mampu menjelaskan nilai perusahaan sebesar $40,89 \%$ dan $42,51 \%$.

Sebagaimana dapat dilihat pada Tabel 3, dalam model 1 (Persamaan 1), variabel ROA memiliki probabilitas sebesar 0.335. Dengan menggunakan tingkat keyakinan 95\%, dapat disimpulkan bahwa hipotesis H1 ditolak. Dengan kata lain, variabel ini tidak signifikan mempengaruhi nilai perusahaan. Apabila uji signifikansi diperoleh kesimpulan tidak terdapat hubungan yang signifikan, maka uji arah untuk variabel bebas ini tidak perlu dilakukan sehingga tidak perlu melihat lebih lanjut nilai $t$-statistic.

Dalam model 1 (Persamaan 2), probability dari variabel ROA adalah sebesar 0.101. Dapat disimpulkan variabel ini tidak signifikan mempengaruhi nilai perusahaan. Uji signifikansi diperoleh kesimpulan bahwa tidak terdapat hubungan antara profitabilitas dengan nilai perusahaan maka uji arah untuk variabel bebas ini tidak perlu dilakukan 
Variabel pengungkapan elemen IR merupakan variabel yang dilakukan analisis menggunakan model regresi moderasi (MRA). Menurut Ghozali \& Ratmono (2016), uji MRA merupakan pengujian linear berganda yang dalam persamaan regresinya mengandung unsur interaksi antar variabel. Variabel IR dan variabel ROAIR merupakan variabel interaksi yang menggambarkan pengaruh IR terhadap PBV. Dalam menjawab hipotesis, dilakukan analisis hasil pengolahan data menggunakan model 1 (Persamaan 2). Dapat dilihat pada Tabel 3, dalam model 1 (Persamaan 2), probability dari variabel integrated reporting (ROAIR) sebagai variabel moderasi adalah sebesar 0.09. Dengan menggunakan tingkat keyakinan 95\%, dapat disimpulkan bahwa hipotesis H2 ditolak. Dengan kata lain, variabel tidak signifikan mempengaruhi hubungan antara profitabilitas dengan nilai perusahaan. Dengan kesimpulan tidak terdapat hubungan yang signifikan, uji arah untuk variabel bebas ini tidak perlu dilakukan sehingga tidak perlu melihat lebih lanjut nilai $t$-statistic.

Berdasarkan output hasil regresi fixed effect dalam melihat hubungan variabel independent dan variabel dependen, dapat diringkas menjadi tabel analisis hubungan dapat dilihat pada Tabel 4.

Tabel 4. Tabel Analisis Hubungan

\begin{tabular}{|c|c|c|c|c|c|}
\hline \multirow[b]{2}{*}{ Variabel } & \multicolumn{5}{|c|}{ Model 1 (Persamaan1) Model 1 (Persamaan 2) } \\
\hline & Coeff & Prob & Coeff & Prob & Keterangan \\
\hline ROA & 0 & 0.3355 & 0 & 0.101 & $0=$ tidak \\
\hline ROAIR & NA & NA & 0 & 0.180 & $\begin{array}{l}\text { NA }=\text { tidak dimasukan } \\
\text { dalam pemodelan } \\
0=\text { tidak }\end{array}$ \\
\hline SIZE & 0 & 0.111 & 0 & 0.166 & mempengaruhi \\
\hline LEV & + & 0.000 & + & 0.000 & $+=$ berbanding lurus \\
\hline
\end{tabular}

Sumber: Data Penelitian, 2020

Berdasarkan Tabel 4, terkait analisis hubungan antar variabel, hasil penelitian ini menyimpulkan bahwa variabel profitabilitas perusahaan tidak memiliki hubungan yang signifikan terhadap nilai perusahaan. Hasil ini dimungkinkan dapat terjadi karena perusahaan memiliki pilihan menggunakan keuntungan yang diperoleh menjadi laba ditahan dan tidak dibagikan kepada pemegang saham. Investor masih perlu menimbang informasi yang dihasilkan dari profitabilitas karena adanya opsi laba ditahan dan pembagian dividen yang ditindaklanjuti oleh perusahaan. Adanya opsi tersebut dapat menimbulkan sentimen positif jika sesuai harapan investor dan dapat pula menimbulkan sentimen negatif jika tidak sesuai harapan investor. Hal ini sesuai dengan dengan penelitian Tarima (2016) yang menyatakan bahwa profitabilitas tidak berpengaruh signifikan terhadap nilai perusahaan. Perusahaan menggunakan keuntungan tersebut untuk laba ditahan dan tidak dibagikan kepada pemegang saham sehingga tidak berpengaruh signifikan terhadap nilai perusahan. Perbedaan lainnya adalah penelitian ini memiliki nilai rata-rata ROA yang tidak berubah signifikan dari tahun ke tahun sehingga value informasi berupa profitabilitas yang disampaikan terhadap investor tidak memberikan sinyal atau nilai tambah. Hal ini juga diperkuat oleh penelitian Thaib \& Dewantoro (2017) yang menyatakan bahwa profitabilitas tidak begitu berpengaruh terhadap nilai perusahaan pada 
perusahaan transportasi laut di Indonesia. Perusahaan pelayaran memiliki ratarata profitabilitas yang rugi sedangkan nilai perusahaan rata-rata memiliki nilai yang stagnan.

Berbeda dengan hasil penelitian oleh Mufidah \& Purnamasari (2018) yang menunjukan bahwa laba/profit berpengaruh terhadap nilai perusahaan. Apabila perusahaan mengalami penurunan laba, para investor mengambil keputusan untuk lebih memilih mengamankan uangnya dengan menarik investasi mereka secara besar-besaran. Penelitian di BEI lainnya seperti yang dilakukan oleh Wijaya \& Sedana (2015) terhadap sektor properti juga menyatakan bahwa profitabilitas berpengaruh terhadap nilai perusahaan. Perbedaan tersebut mungkin terjadi karena penelitian-penelitian terdahulu hanya mengamati satu sektor industri atau hanya perusahaan yang memiliki karakteristik khusus seperti BUMN yang merupakan perusahaan milik negara. Perbedaan tahun penelitian juga terjadi seperti penelitian terdahulu yang mengamati rentang tahun 2012-2016. Pada rentang tahun tersebut, terdapat gejolak ekonomi yang tidak menentu sehingga terjadi perubahan nilai ROA dari tahun ke tahun yang cukup signifikan.

Elemen-elemen integrated reporting dianggap berpengaruh terhadap hubungan profitabilitas dengan nilai perusahaan karena perusahaan mengungkapkan informasi elemen-elemen bersifat non-angka yang menghasilkan pengaruh berupa sinyal atau tanggapan investor terhadap informasi tambahan perusahaan. Dalam teori keagenan, manajemen melakukan tindakan intermediaries yaitu menyajikan laporan perusahaan yang memberikan informasi memadai kepada stakeholder sehingga diharapkan adanya laporan yang terintegrasi. Informasi ini juga dapat menghilangkan asimetri informasi yang awalnya hanya bersifat angka-angka menjadi lebih lengkap berupa informasi nonangka yang mampu menjelaskan informasi angka.

Berdasarkan Tabel 4, terkait analisis hubungan antar variabel, hasil penelitian ini menyimpulkan bahwa variabel pengungkapan elemen IR tidak memiliki pengaruh terhadap hubungan profitabilitas dengan nilai perusahaan. Hasil ini dimungkinkan dapat terjadi karena nilai informasi elemen IR yang bersifat non-angka tidak terlalu berkaitan dengan informasi yang bersifat angka dalam laporan perusahaan khususnya dalam profit. Nilai informasi yang ditambahkan oleh perusahaan hanya bersifat kepatuhan saja atau bisa dikatakan informasi ini sekedar ada untuk memenuhi aturan OJK dan Bapepam-LK. Elemen seperti prospek perusahaan yang hanya sekedar ada di laporan namun tidak dikaitkan dengan data kondisi eksternal ekonomi perusahaan atau elemen strategi perusahaan yang dibuat namun tidak memiliki keterkaitan dengan rencana dan tujuan (memperoleh keuntungan) perusahaan. Dengan begitu, elemen IR dianggap tidak memberikan nilai tambah informasi sehingga tidak mendapat sinyal yang kuat dari investor. Hasil yang sama dilakukan dalam penelitian Sebti (2019) yang menyatakan bahwa IR belum mampu memberikan nilai sesuai dengan kualitas perusahaan. Informasi IR tidak mampu mempengaruhi investor dalam mengambil keputusan investasinya. Perbedaan lainnya adalah elemen IR tidak menghilangkan informasi asimetri yang terjadi. Informasi sukarela dari pengungkapan elemen-elemen IR tidak terlalu memberikan value informasi kepada investor. Hal ini sama dengan penelitian Khairina (2018) bahwa 7 (tujuh) 
dari 8 (delapan) elemen IR tidak memberikan pengaruh yang signifikan terhadap informasi asimetri.

Berdasarkan Tabel 4, dalam model 1 dan model 2, dapat disimpulkan bahwa variabel kontrol berupa SIZE tidak memiliki hubungan yang signifikan terhadap nilai perusahaan. Dengan demikian, ukuran perusahaan tidak berpengaruh terhadap nilai perusahaan yang artinya ukuran perusahaan bukan menjadi pertimbangan investor dalam mengambil keputusan investasinya. Hasil penelitian ini berbeda dengan penelitian yang dilakukan Sari \& Priyadi (2016) yang menyatakan bahwa semakin besar SIZE membuat kualitas perusahaan lebih dikenal masyarakat. Perusahaan menjadi lebih mudah dalam mendapatkan modal atau dana dari investor.

Penyebab tidak berpengaruhnya variabel ukuran perusahaan terhadap nilai perusahaan dapat terjadi karena semakin besar ukuran perusahaan tidak terlalu membuat kualitas perusahaan semakin baik. Hal ini sesuai dengan penelitian oleh Agustina, Sutriswanto, \& Apriyanto (2020) yang menyatakan pertumbuhan perusahaan, CSR dan ukuran perusahaan belum mampu membentuk image perusahaan yang dapat memiliki impact terhadap nilai perusahaan. Perbedaan lainnya terjadi karena ukuran perusahan merupakan informasi yang tidak terlalu diperhatikan oleh investor. Hasil penelitian ini sesuai dengan penelitian Suwarno, Puspito, \& Qomariya (2016) bahwa investor tidak melihat jumlah aset sebagai salah satu faktor dalam melakukan investasi. Investor juga perlu meninjau dari sisi laporan keuangan, nama baik dan kebijakan dividen.

Leverage dikatakan memiliki pengaruh terhadap nilai perusahaan sebagaimana dijelaskan sebelumnya, Semakin banyak hutang, maka perusahaan akan memiliki risiko gagal bayar yang tinggi. Hal ini dapat memberikan sinyal negatif berupa penurunan kepercayaan publik sebagai akibat keraguan investor terkait bagaimana perusahaan membayar beban bunga dan pokok hutang tersebut.

Berdasarkan Tabel 4, dalam model 1 dan model 2, rasio hutang terhadap modal memiliki pengaruh yang signifikan terhadap nilai perusahaan dan memiliki hubungannya positif. Hasil penelitian ini sama dengan penelitian yang dilakukan oleh Sari \& Priyadi (2016) bahwa leverage memiliki pengaruh terhadap nilai perusahaan tetapi penelitian ini memiliki arah yang berbeda.

Sari \& Priyadi (2016) menyatakan tingginya hutang perusahaan akan berdampak terhadap kepercayaan publik kepada perusahaan. Perusahaan akan mengalami financial distress atau kesulitan dalam membayar hutang. Penyebab perbedaan ini dimungkinkan terjadi karena penggunaan hutang memiliki lebih banyak benefit daripada biaya hutang yang ditimbulkan. Perusahaan masih dapat membayar beban dan pokok bunga dengan baik seiring benefit yang dihasilkan. Hasil penelitian ini sesuai dengan penelitian Pratama \& Wiksuana (2016) menyatakan bahwa leverage berpengaruh positif signifikan terhadap nilai perusahaan. Penggunaan utang yang lebih banyak akan memberikan benefit pada perusahaan sampai pada titik puncaknya untuk dapat mengoptimalkan potensi yang dimiliki. Perbedaan lainnya mungkin terjadi karena perusahaan tidak mengalami financial distress karena rasio hutang masih dapat diatasi oleh ekuitas perusahaan yang terlihat dari rasio DER kebanyakan berada dibawah nilai 1 (satu). Hasil ini sesuai dengan penelitian Adenugba, Ige, \& Kesinro (2016) yang 
menyatakan leverage memiliki efek positif signifikan terhadap nilai perusahaan. Pendanaan yang bagus melalui hutang dapat membantu perusahaan membiayai proyek jangka panjangnya dan mengurangi beban pajak perusahaan

\section{SIMPULAN}

Berdasarkan data dan analisis yang diuraikan, dapat diambil beberapa simpulan berupa profitabilitas tidak berpengaruh terhadap nilai perusahaan. Dalam membuat keputusan investasi, investor untuk tidak menjadikan profit sebagai bahan pertimbangan utama. Investor hendaknya perlu menimbang informasi lain yang dihasilkan baik dari unsur profitabilitas seperti besaran laba ditahan dan pembagian dividen maupun dari unsur non profitabilitas. Elemen IR tidak memiliki pengaruh terhadap hubungan profitabilitas dengan nilai perusahaan. Hal ini dapat terjadi karena nilai informasi elemen IR yang bersifat non-angka tidak terlalu berkaitan dengan informasi yang bersifat angka dalam laporan perusahaan khususnya dalam profit dalam mempengaruhi nilai perusahaan. Nilai informasi yang ditambahkan oleh perusahaan hanya bersifat kepatuhan saja. Elemen seperti prospek perusahaan yang hanya sekedar ada di laporan namun tidak dikaitkan dengan data kondisi eksternal ekonomi perusahaan atau elemen strategi perusahaan yang dibuat namun tidak memiliki keterkaitan dengan rencana dan tujuan (memperoleh keuntungan) perusahaan.

Dalam menyusun penelitian ini tentunya terdapat beberapa keterbatasan seperti variabel dependen yang digunakan belum tentu menggambarkan secara utuh pengaruhnya terhadap nilai perusahaaan. Tahun penelitian 2019 tidak dapat diambil karena adanya pandemi COVID-19 dan terdapat keterbatasan waktu dalam penelitian ini. Selanjutnya, jumlah sampel yang digunakan merupakan perwakilan dari masing-masing sektor. Belum tentu sampel yang dipilih dapat mewakili secara keseluruhan sektor tersebut. Satu atau beberapa sektor industri kemungkinan memiliki karakteristik bentuk laporan perusahaan yang sedikit berbeda, seperti sektor minyak dan gas, yang memiliki aturan lebih detail sebagaimana tertuang dalam pedoman tata kerja SKK Migas.

Beberapa saran yang dapat diberikan kepada pihak-pihak terkait seperti penambahan beberapa variabel seperti variabel rasio pembayaran dividen atau variabel pertumbuhan penjualan agar dapat menggambarkan secara utuh pengaruhnya terhadap nilai perusahaan. Memperbanyak rentang waktu tahun penelitian akan membuat semakin baik dalam menggambarkan fenomena yang terjadi. Menambah sampel penelitian dalam masing-masing sektor, atau mengambil sampel tidak dengan cara perwakilan dari sektor atau fokus pada sektor tertentu sehingga sampel dapat menggambarkan fenomena industri secara keseluruhan.

\section{REFERENSI}

Adenugba, A. A., Ige, A. A., \& Kesinro, O. R. (2016). Financial leverage and firms' value: a study of selected firms in nigeria. European Journal of Research and Reflection in Management Sciences.

Agustina, R., Sutriswanto, \& Apriyanto, G. (2020). Study of capital structure (idx 2011-2017): Firm growth, firm size, and csr disclosure on firm value. International Research Journal of Advanced Engineering and Science, 5(1), 128-133. 
Barth, M. E., Cahan, S. F., Chen, L., \& Venter, E. R. (2017). The economic consequences associated with integrated report quality: Capital market and real effects. Accounting, Organizations and Society. https://doi.org/10.1016/j.aos.2017.08.005

Ghozali, I., \& Ratmono, D. (2016). Analisis Multivariat dan EkonometrikaTeori, Konsep, dan Aplikasi dengan Eviews 8. Universitas Diponegoro. Semarang: Badan Penerbit Universitas Diponegoro.

Gordon, M. J. (1959). Dividends, Earnings, and Stock Prices. The Review of Economics and Statistics, 41(2), 99. https:// doi.org/10.2307/1927792

IIRC. (2011). Summary of responses to the september 2011 discussion paper and next steps.

Jusriani, I. F., \& Rahardjo, S. N. (2013). Analisis pengaruh profitabilitas, kebijakan dividen, kebijakan utang, dan kepemilikan manajerial terhadap nilai perusahaan (studi empiris pada perusahaan manufaktur di BEI periode 20092011). Diponegoro Journal of Accounting, 2(2), 168-177.

Khairina, D. (2018). Pengaruh integrated reporting terhadap asimetri informasi (studi empiris pada perusahaan manufaktur sektor real estate dan konstruksi bangunan periode 2013-2016). Universitas Islam Indonesia.

Kustiani, N. A. (2016). Penerapan elemen-elemen integrated reporting pada perusahaan yang terdaftar di bursa efek indonesia. Jurnal Info Artha, 3, 43-54. https://doi.org/http://dx.doi.org/10.31092/jia.v3i0.38

Lang, L. H. P., \& Litzenberger, R. H. (1989). Dividend announcements: Cash flow signalling vs. free cash flow hypothesis? Journal of Financial Economics, 24(1), 181-191. https:/ / doi.org/https:/ / doi.org/10.1016/0304-405X(89)90077-9

Lee, K.-W., \& Yeo, G. H.-H. (2016). The association between integrated reporting and firm valuation. Review of Quantitative Finance and Accounting, 47(4), 12211250. https://doi.org/10.1007/s11156-015-0536-y

Lisa. (2013). Integrated reporting, teori dan aplikasi. Retrieved from https:/ / www.slideshare.net/lisah1 diakses April 2020

Martina, M. (2019). Pengaruh pengungkapan integrated reporting terhadap nilai perusahaan. UMM.

Muamar, Y. (2019). Prospek cerah, investor borong saham wika gedung. Retrieved from https://www.cnbcindonesia.com/market/20190523105350-1774528/ prospek-cerah-investor-borong-saham-wika-gedung

Mufidah, N., \& Purnamasari, P. E. (2018). Pengaruh profitabilitas terhadap nilai perusahaan dengan pengungkapan corporate social responsibility dan good corporate governance sebagai variabel moderating. El Dinar: Jurnal Keuangan Dan Perbankan Syariah, 6(1), 64.

Prasetio, F. W. (2019). Perspektif: saatnya berburu saham-saham murah. Retrieved from https://market.bisnis.com/read/20190415/7/911962/ perspektifsaatnya-berburu-saham-saham-murah

Pratama, I. G. B. A., \& Wiksuana, I. G. B. (2016). Pengaruh Ukuran Perusahaan Dan Leverage Terhadap Nilai Perusahaan Dengan Profitabilitas Sebagai Variabel Mediasi. E-Jurnal Manajemen; Vol 5 No 2 (2016). Retrieved from https://ojs.unud.ac.id/index.php/Manajemen/article/view/17498

Rahmayanti, E. (2017). Harga saham JAWA naik 21\%, tapi perusahaan masih merugi. 
Saleh, T. (2019). Walau 12 Tahun Merugi, Saham Smartfren Sudah Meroket 132\%! Santoso, A., \& Ariefiantoro, T. (2019). No Title. Tirtayasa Ekonomika, 14(2), 220-230. https://doi.org/http://dx.doi.org/10.35448/jte.v14i2.6477

Sari, R. A. I., \& Priyadi, M. P. (2016). Pengaruh leverage, profitabilitas, size, dan growth opportunity terhadap nilai perusahaan. Jurnal Ilmu Dan Riset Manajemen (JIRM), 5(10), 1-17.

Sebti, N. I. (2019). PengaruhIntegrated Reporting Terhadap Nilai Perusahaanyang Dimoderasi oleh Kompleksitas Organisasi dan Pembiayaan Eksternal di Asia. Universitas Negeri Malang.

Sucuahi, W., \& Cambarihan, J. M. (2016). No Title. Accounting and Finance Research, 5(2), 149-153. https:/ / doi.org/https:/ / doi.org/10.5430/afr.v5n2p149

Suwarno, S., Puspito, A., \& Qomariya, N. (2016). No Title. In Seminar Nasional dan Call Paper (pp. 1-13). Jember: Universitas Muhammadiyah Jember. Retrieved from

http://jurnal.unmuhjember.ac.id/index.php/sncp/article/view/207/136

Tarima, G. (2016). Pengaruh Profitabilitas, Keputusan Investasi Dan Keputusan Pendanaan Terhadap Nilai Perusahaan Farmasi Yang Terdaftar Di BEI Periode 2011-2014. Jurnal Berkala Ilmiah Efisiensi, 16(4), 465-474.

Thaib, I., \& Dewantoro, A. (2017). Pengaruh profitabilitas dan likuiditas terhadap nilai perusahaan dengan struktur modal sebagai variabel intervening. Jurnal Riset Perbankan Manajemen Dan Akuntansi (JRPMA), 1(1), 25-44.

Titman, S., Keown, A. J., \& Martin, J. D. (2018). Financial Management: Principles and Applications (13th ed.). Harlow: Pearson.

Wijaya, B. I., \& Sedana, I. B. P. (2015). Pengaruh Profitabilitas Terhadap Nilai Perusahaan (Kebijakan Dividen Dan Kesempatan Investasi Sebagai Variabel Mediasi). E-Jurnal Manajemen; Vol 4 No 12 (2015). Retrieved from https://ojs.unud.ac.id/index.php/Manajemen/article/view/15500 